\title{
ROLE OF FLOW BETWEEN JOB DEMAND AND JOB RESOURCES AMONG THE HOTEL EMPLOYEES IN SARAWAK
}

\author{
Mark Kasa* \\ USCI University Malaysia \\ Zaiton Hassan \\ University Malaysia Sarawak \\ Jackelyn Ng \\ UCSI University Malaysia \\ Abdul Halim Busari \\ Universiti Malaysia Sarawak \\ Nik Norsyamimi Md. Nor \\ Universiti Malaysia Sarawak
}

\begin{abstract}
The Job Demand-Resources (JD-R) Model has been used to investigate many work outcomes. However, few focused its effects to in-role performance work outcomes and none on flow as mediator in an eastern context. Thus, the objectives of this study are to examine the relationship between flow and in-role performance as well as whether flow mediates the relationship between antecedents (job demand and job resources) and inrole performance among East Malaysian hotel employees. 290 full time frontline and backline employees from four- and five-star rated hotel in Sarawak responded the self-administered questionnaire. Data was analyzed with SPSS version 22 and PROCESS approach. Results confirmed that flow experience positively correlates with in-role performance while also imposes a robust mediating effect between job resources and in-role performance. However, results have shown that flow has no mediation impact on the relationship between job demand and in-role performance. Precisely, hotel employees with provision of sufficient job resources (such as autonomy, social support, performance feedback, possibilities for professional development) are further likely to encounter flow experience, and as a result, are likely to exhibit better inrole performance. Thus, hotel management should redesign jobs and commensurate tasks to encourage flow experiences, which in return lead to better in-role performance that directly contributes to overall performance of the hotel. In addition, management should provide for job resources to encourage task autonomy and better social support systems.
\end{abstract}

Keywords: Job demands; Job resources; Flow; In-role performance; JD-R; Hotel

Received: 16 August 2017

Accepted: 23 August 2019

\footnotetext{
- Corresponding author: Mark Kasa, Faculty of Hospitality \& Tourism Management UCSI University Malaysia, Lot 2864 (P/L 1319), Block 7, Muara Tebas Land District, Isthmus, 93450 Kuching, Sarawak. Email: markedmund@ucsiuniversity.edu.my
} 


\section{INTRODUCTION}

Tourism is one of the major contributors to Malaysian economy with the Hotel industry playing the vital role. Travel and Tourism sector in Malaysia has generated approximately RM65.7 billion directly towards the Malaysian GDP in 2017. Additionally, a total of 670,000 jobs - contributing $4.6 \%$ towards total employment - were directly developed in the year of 2017 with the anticipation to ascent $1.1 \%$ in 2018 . The said industry stakes about $4.8 \%$ of the overall Malaysian GDP share of the 'cake (Turner, 2018). Recently, as recorded by the Ministry of Tourism Malaysia, the industry contributes RM84.1 billion to Malaysian economy with 26 million tourist arrivals to Malaysia which leads to an increase of tourism expenditures in 2018 (Ismail \& Azmi, 2019).

In Malaysia, tourism is acknowledged as one of the important players of the National Key Economic Areas in the vision of the Malaysian government to facilitate Malaysia towards becoming a high-income country by 2020 ("Tourism sector to remain", 2017). According to the Malaysian Investment Development Authority (2019), Malaysia aims to yield RM168 billion for the country by 2020; consistent with Malaysia Tourism Transformation Plan and it was supported by past researches that hotels serve as key providers within the tourism industry (Hayes \& Ninemeier, 2007; Information Communications and Culture, 2011). The Malaysian hospitality industry has advanced very expeditiously in a consistent manner alongside the tourism industry; the numbers of new hotels and rooms have increased exponentially over the years. A hotel's performance revolves around the supplies of quality services to customers with the challenge of producing motivated employees capable of facilitating the endeavor (Mokaya, Musau, Wagoki \& Karanja 2013). Furthermore, there is no valid approach or method to adopt flow experience as a positive approach to better improve and enhance the hotel industry in Sarawak in an effort to increase and enhance the overall operation, management standard and service quality, as well as to add competitive value to the hotel employees. Meanwhile, the study on flow with in-role performance is virtually non-existent, particularly in Sarawak's hotel setting. Due to the gap in this area of research which integrates the context of Sarawak, this present study will add to the body of knowledge in the field of flow particularly in human resource development field.

The hotel industry workforce, particularly the frontline employees who have direct contact with customers, play an important role in service aspect as service is an intangible item which can only be produced via experience. Customers' satisfaction in this case is the key towards hotel industry's success (Xie \& Chaipoopirutana, 2014). As the number of hotel service providers across the globe with access to hotel review sites increases, customers' satisfaction is the main key driver to be sustainable and competitive (Mulyana \& Pramento, 2018). Seeing that frontline employees communicate directly with hotel guests and represent the hotel throughout delivering service process, their attitudes and behaviours are crucial in delivering the services to hotel guests. In order to deliver quality service, employees' performance comes into play and is essential for every organization - particularly those of service industry. The organization ought to take employees' performance enhancement into account by encouraging the employees to carry out work tasks efficiently and effectively via provision of sufficient resources (such as granting authority at task level and providing employees with regular performance feedback at supervisory level). Preceding researches have deduced that engaged employees are more loyal and committed to their current organization (Bakker, Demerouti, \& Lieke, 2012; De Clercq, Dimov, \& Thongpapanl, 2010; Karatepe \& Olugbade, 2009) whereas the non-engaged counterparts will influence the hotel performance in aspects of decreased productivity, increased recruitment and training cost, and 
increased absenteeism as well as increased turnover. Hence, it is important to cultivate motivation among the employees and build the customer loyalty which derive from performing staff.

Nevertheless, the hospitality sector continues to be the most favourable industry with a high rate of turnover (Amin \& Akbar, 2013) and contributed nearly twice from the average rate compared to other industries (Deloitte, 2010) and is expected to escalate drastically once the economic downturn recovers (Deloitte, 2010; Davis, 2013). Additionally, though Malaysian employment rate in hospitality industry is high, the attrition rate is twofold that of the general workforce of Malaysia $(\mathrm{Ng}, 2015)$. Working in the hotel line is often considered as high failure rate and poor performance in business generation and revenue projection matters and is one of the service components that needs to be supported toward service climate (Dimond, 2004). Service climate is defined as when the hotel emphasizes on quality services and customer satisfaction. However, the service climate in the hotel industry is still lacking the enhancement with positive psychological capacities (Schneider, Bowen, Ehrhart \& Holcombe as cited in Ashkanasy, Wilderom, \& Peterson, 2000). Csikszentmihalyi (1997) clarified flow as a positive psychological experience that may exist in conditions where activity is present, and numerous findings have been discovered in various distinctive activities such as playing music, sports and work (Catley \& Duda, 1997; Csikszentmihalyi \& LeFevre, 1989; Kowal \& Fortier, 1999). Additionally, majority of research studies regarding on JD-R theory has yet to report on flow as mediator and of in-role performance as outcome (Bakker, Demerouti \& Verbeke, 2004). To sum up, this study is purposed to examine the mediating role of (1) flow experience between job demand and in-role performance and (2) mediating role of flow between the job resources and in-role performance. Lastly (3), this study examines flow positively related with in-role performance.

Several researchers have explained the presence of flow experience is essential for remarkable organizational productivity, performance and success while having high potentiality in posting influence on employee retention, productivity and loyalty, with relation to customer satisfaction, organizational reputation as well as overall stakeholder value (Harter, Schmidt, \& Hayes, 2002; Schaufeli \& Bakker, 2004; Xanthopoulou, Bakker, Demerouti, \& Schaufeli, 2009; Bakker \& Demerouti, 2007; Hallberg \& Schaufeli, 2006; Lewicka, 2011; Saks, 2006). A number of studies have been carried out on the predictors of work engagement yet these studies were predominantly focalized on developed western countries such as the United States (Britt, 2003; May, Gilson, \& Harter, 2004), Netherlands (Schaufeli \& Bakker, 2004; Xanthopoulou, Bakker, Demerouti, \& Schaufeli, 2007), Germany (Weigl et al., 2010), Spain (Salanova, Agut, \& Peiró, 2005), Finland (Hakanen, Bakker, \& Schaufeli, 2006; Mauno, Kinnunen, \& Ruokolainen, 2007), and Australia (Parker, Jimmieson, \& Amiot, 2010). Additionally, the mentioned researches were carried out within specific service industries - such as airline, education, healthcare and insurance. Nonetheless, in spite of increasing focus concerning flow experience, studies in the said area is still in its outset in Malaysia (Hamid \& Yahya, 2011). To the best of the authors' knowledge, there is still a lack of studies being done concerning to flow experience playing the role as mediator in the service industry, particularly in hotels. The current study is distinctive to previous study in the sense that the subject studied is in eastern context and particularly in service industry (i.e. hospitality) emphasizing on the role of flow experience as mediator to explore insights that can be helpful to hotel organizations to find practical ways in cultivating the motivation among its employees, boost their performance that can result in increased customer satisfaction via quality service delivery while increasing the organizational performance and overall stakeholder values. 
Among the most immense and valuable asset to any organizations, particularly to hotel industry due to its serviced-based nature, is human resource. Individuals that are qualified and motivated are able to constitute and deliver value from the organizational resources. All forward-looking hotel organization not only ought to captivate desirable employees, it should also create and keep up employees' motivation to work in a dynamic working environment. Motivated employees may turn into competitive advantage of an organization. The primary factors which lead hospitality career to be unappealing includes working on long hours or irregular schedule, meagre pay, work pressure, uncertain and intermittent employment - upon which significantly reduce performance that in turn leads to low service quality and eventually may cause turnover intention due to low employee satisfaction (Brown, Thomas \& Bosselman, 2015; Kasa, Hassan \& Yatim, 2018), in addition to the highest jobs created and labor demand were mostly by the service sector as reported by the Department of Statistic Malaysia (Mahidin, 2019).

\section{LITERATURE REVIEW}

\subsection{Flow Experience as Positive Phenomena}

Flow experience is a conscious condition in which individuals become entirely pleasurably absorbed in an activity. Various individuals have described "feeling a sense of effortless action in outstanding moments", which were descriptive of peak or optimal experience (Csikszentmihalyi, 1990). This suggested that the pleasure and its resultant intrinsic motivation, total immersion or involvement in an activity appear to be a central aspect of flow (Csikszentmihalyi, 1990). Earlier investigation by Csikszentmihalyi and LeFevre, (1989) explained this as flow theory, where an activity become autotelic and affects work satisfaction.

Bakker (2008) construed that flow was a short-term peak experience which is characterized by an absorption as described by "a complete consolidation of effort state" where a person is wholly immersed in "one's job task and nothing else seems to matter" (Csikszentmihalyi, 1990; Bakker, 2008) identified that work enjoyment as simultaneous joyful feeling and high judgment work life quality (Veenhoven, 1984, 1999). Bakker (2008) identified intrinsic work motivation which was "the desire to execute" task with intend to gain both pleasure and gratification (Diener, 2000; Diener \& Diener, 1996). The positive mood generated by flow experience is capable of developing creativity and positive thinking (Kasa \& Hassan, 2013). In basic term, employees that encounter flow experience are typically completely engrossed in completing the task that is perceived as notably rewarding and valuable. Antecedents such as job characteristics (Demerouti, 2006), job resources (Makikangas, Bakker, Aunola, \& Demerouti, 2010), personal and organizational resources (Bakker, Demerouti \& Schaufeli, 2003) and burnout (Schaufeli \& Bakker, 2004) proved to be either positively or negatively correlated. In addition, past studies also revealed favourable result that flow is positively related with subjective well-being, happiness, positive behaviors, life satisfaction (Chen, Wigand \& Nilan, 1999; Straume \& Vittersø, 2015), employee productivity (Csikszentmihalyi, 2003), positive mood (George \& Brief, 1992), loyalty (Zhou, Li, \& Liu, 2010) and taking on extra-role voluntarily (Engeser, Jones, Stiglhamber, Shanock, \& Randall, 2005). Reena and Jayan (2012) reported that when flow was applied at the work situation, people made very positive judgments about their working quality. Csikszentmihalyi (2003) advocated that promoting a flow experience through a cultivating and challenging work, a restaurant manager may have higher level of professional skills in mitigating customer's complaint about poor attitude 
and sub-standard services delivered by the staff. Goals in handling complaints professionally will specifically be achieved when a manager has a particular professional skill sets (Edwards, 1996) or when there are adequate workplace resources of colleague's support, autonomy and performance feedback (Bakker, Demerouti, De Boer, \& Schaufeli, 2003; Demerouti et al., 2001).

Unfortunately, various past studies focused only on antecedents and outcomes but there is insufficiency when it comes to the inclusion of positive psychological experience; flow as mediator in job demand-resources model. Based on the preceding studies, the hypotheses are formulated subsequently;

Hypothesis 1. Flow mediates the relationship between job demand and in-role performance. Hypothesis 2. Flow mediates the relationship between job resources and in-role performance. Hypothesis 3 . There is a significant relationship between flow and in-role performance.

Figure 1: Study Framework

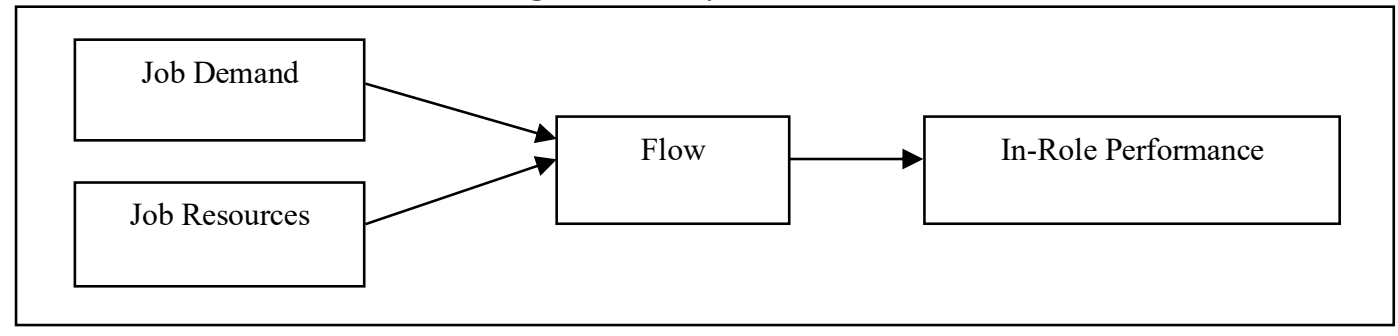

\subsection{In-role Performance}

In-role performance refers to the behaviors that are formally required by a firm and such performance contributes directly towards to goals of the firm (Motowidlo \& Van Scotter, 1994). Csikszentmihalyi (2003) proposed the idea of individual employees perform better when they become immersed in their job due to being happy and intrinsically motivated, which seems to be credible and persuasive. As mentioned earlier, flow is characterized by absorption, work enjoyment and intrinsic work motivation. Limited studies reported on their prediction which shows a significant relationship between absorption and work enjoyment with in-role performance (Csikszentmihalyi, 1990; Bakker, 2008) while there is still no known study reporting on intrinsic work motivation positively correlating with in-role performance. Hence, the third hypothesis is formulated as: Flow is positively related with in-role performance.

\subsection{Job Demands-Resources Model}

The JD-R model (Bakker \& Demerouti, 2007; Bakker, Demerouti, Taris, Schaufeli, \& Schreurs, 2003; Bakker et al., 2004; Demerouti, Bakker, Nachreiner, \& Schaufeli, 2001) is a heuristic model in which it "enumerates in what manner that the well-being of employee can be produced" within the said employee's working conditions. It was understood that the JD-R model was characterized by two processes (1) overcoming various employee thresholds by using their relevant job attributes and (2) manipulating employees' motivational processes (autonomy, social support, performance feedback and possibilities for professional development). The model believed that the gamut of 
job demands incurs an employee physiological and/or psychological cost (Hockey, 1997) which necessitates certain processes to mitigate. Job resources commonly refer to the physical, social or organizational aspects of one's job and supporting an employee's motivational processes can result in better functional, physiological and psychological outcomes and positive personal development which can in turn help attain work-related goals (Demerouti et al., 2001; Bakker \& Demerouti, 2007). It is illustrated that job resources are the primary facilitators of employees' flow experience which results in the enhancement of performance according to the motivational process of job demands-resources (JD-R) model (Bakker \& Demrouti, 2007). These characteristic and processes of the JD-R Model was considered suitable to meet the objectives of investigating the flow in predicting in-role performance.

The present study is significant in one way or another in terms of theoretical, empirical as well as practical aspects. Firstly, the present study aims to scrutinize the relationship between flow and inrole performance on top of the relationship between antecedents (job demand and job resources) and in-role performance with flow as mediator. As reported by Kasa \& Hassan (2013), majority of precedent studies conducted in the subject matter of flow experience focused primarily on advanced western nations such as Canada, Europe, United Kingdom and the United States. In other words, there are only definite studies on flow experience among hotel employees in Malaysian context, particularly Sarawak (Kasa et al., 2018). Secondly, the present study adds to the current literature in empirical terms by examining the antecedents of flow experience. Furthermore, this study also broadens the current knowledge base through investigating the mediator role of flow experience of the relationship of job demands and job resources on in-role performance by collecting data from the hotel industry in East Malaysia (particularly Sarawak), an eastern country. Lastly, the results of the present study are beneficial and helpful not only for industry professionals but also hospitality educators and graduates. For instance, managers of different departments in the hotel industry can improve their knowledge on what motivates their employees in beliefs that unfavorable backlash of motivation dip will not lead to failure in delivery of service and turnover

\section{RESEARCH METHOD \& INSTRUMENTS}

A quantitative approach was employed through survey questionnaire with purposive sampling as data collection method as this study is directed towards full time hotel employees serving in Sarawak's hotels that are certified by the Malaysian Association of Hotels (MAH). Purposive sampling is typically adopted when researchers single out samples representatives to conform certain precedents (Cooper \& Schindler, 2003). In this case, the researcher particularly desired to examine the interactions between factors including individual's job demands and/ or job resources, flow experience, and in-role performance as well as how these factors influence the in-role performance. Moreover, this study has selectively chosen MAH certified hotels due to its worthiness to study; members under this association have to demonstrate that it meets or exceeds industry quality and standards based on the quality measurements developed under MAH. Furthermore, this association does not only vet the service quality provided by its member with business ethics and standards but also ensure its members constantly uphold the criterion by providing beneficial training. Thus, this explains the reason purposive sampling method is applied for data collection of present study. 
There are approximately 85 hotels identified under the current star rating category in Sarawak based on the statistics provided by MAH. The population targeted by the current study is the employees from hotels based in Sarawak. Raosoft calculation method was used to determine the sampling size for this study, based on the population size of 20,000 since the number of employees in hospitality industry are considerably challenging to measure due to high attrition rate. Grounded on Raosoft calculation method, 5\% margin error and 95\% confidence level were implied with a total population of 20,000 and $50 \%$ response distribution, we came to the recommended sample size of 377 to represent the target population targeted for the current study. A total of 6 hotels from Sarawak have participated in the questionnaires which took approximately 8 weeks for the distribution and collection of questionnaires; the questionnaires were distributed to the respondents in February 2017 and were collected in April 2017. 400 questionnaires were distributed; however, only 290 questionnaires were useable. Of note, this number of sample was higher than the required 107 respondents, which was calculated using $\mathrm{G}^{*}$ Power 3.1.9.2 (with 0.15 effect size and output of parameter of actual power at 0.95). The respondents of present study are particularly hotel employees that work full time in the hotel industry. In addition, the present study focused only on informants from hotel registered and certified by Malaysian Association of Hotel (MAH).

The job demand measurement consists of 18-items about workload (Furda, 1995; Karasek, 1985), emotional demand (Van Veldhoven \& Meijman, 1994) and work-home conflict (Geurts, 2000), 25-items measured job resources on autonomy (Karasek, 1985), social support (Veldhoven \& Meijman, 1994), performance feedback (Bakker et al., 2003; Karasek, 1985) and possibilities for professional development (Bakker et al., 2003). These item rated on a six-point scale ( $1=$ never, 6 $=$ always). In-role performance; utilized the scale developed by Williams and Anderson (1991) and consisted of 7 items which were rated on a six-point scale ranging from (1) strongly disagree to (6) strongly agree. Flow experience was examined with a work-related flow instrument (Bakker, 2008) which comprised of 13 items measuring absorption (4 items), work enjoyment (4 items), and intrinsic work motivation (6 items). Respondents were asked to indicate how often they had each experience during the preceding week $(1=$ never, $6=$ everyday $)$.

To analyze the significant mediating effect between predictors and the outcome, the approach of analysis by Preacher \& Hayes (2004) was utilized. SPSS macros version 22; PROCESS through Model 4 facilitated the estimation of the indirect effect in simple mediation model together with bootstrap approach to obtain the confidence intervals which is one of the powerful and valid methods for testing mediation effect (Mackinnon, Fairchild, \& Fritz, 2007; MacKinnon, Lockwood, $\&$ William, 2004). It was noted that to derive the significant mediation result, the significant value should be above zero or positive value ( $>0 /+$ value) (Preacher \& Hayes, 2004). The bootstrap upper and lower bound value must be above zero or positive value $(>0 /+$ value) (Preacher $\&$ Hayes, 2004).

\section{RESULTS AND DISCUSSION}

In this study, $56 \%$ of respondents were females and $43 \%$ were males. $49 \%$ of the 290 respondents were aged between 21 to 30 years old, whereas $27 \%$ of the total respondents were aged between 31 to 40 years old. More than half of the respondents were single (52\%). In terms of education level, $35 \%$ of the respondents possess only Sijil Pelajaran Malaysia, followed closely by Diploma holders (32\%). 28\% of the respondents completed their Bachelors' degree. Further demographic 
background revealed $57 \%$ of the respondents were made up of operation department while the remaining are from administrative department. $24 \%$ of the total respondents were of managerial positions with the remaining as non-managerial positions.

The result extracted from SPSS is shown in Table 2 below. The reliability $(\alpha)$ value for the job demand, job resources and in-role performance was $0.934,0.930$ and 0.8623 respectively. There were no major issues with normality and outlier testing. Exploratory factor analysis with varimax rotation was utilized to examine the construct validity for all items instrument with factor loading exceeded the value of 0.6. The Kaiser-Meyer-Olkin of Sample Adequacy (KMO) value was 0.871, above the benchmark value of 0.6 (Kaiser, 1974). The Bartlet's Test for the 50 items correlation matrix was highly significant $(\mathrm{p}<.000)$ with Chi-square value of 11265.74 in supporting the factorability of correlation matrix.

The first hypothesis was concerned with the mediating role of flow between job demand and inrole performance. Statistically, flow was not significantly mediated between job demand and inrole performance at 0.128 [LLCI -0.0094, ULCI 0.0843]. Flow did not mediate between job demand and in-role performance. As mentioned by Demerouti et al. (2000, 2001), high job demand may cause exhaustion which may result in energy depletion. An analysis of responses concluded that hotel job demand resulted in employees that were physically and mentally exhausted. Respondents not being able to experience flow nor reaping its benefits in mediating job demands and in-role performance as seen in this particular study.

The second hypothesis proposed that flow mediates the relationship between job resources and inrole performance. Analyses through Andrew Hayes matrix output from regression-based approach proved that the significant indirect effect of flow is related between job resources and in-role performance is significant at $0.000 * *$ [LLCI 0.0932, ULCI 0.2607]. This suggests that flow holds a significant indirect effect to the relationship between job resources and in-role performance. This is similar to the finding that flow experience predictive of job performance while also having multiplicative and positive influence on employees' job performance when motivation strategy is integrated (Barrick \& Mount, 2005; Li, Chen, Chang, \& Kun, 2012). It can be concluded that hotel employees were prone to better achieve their formally obligated job tasks when resources, such as autonomy and social support were provided. This provision influenced the positive probability of encountering flow and the resulting enhancing job performance.

Table 1: Direct, Indirect, and Total Effect

\begin{tabular}{llllll}
\hline \hline Variable & Direct & Indirect & Total & Lower Limit & Upper Limit \\
\hline Job Demand & 0.0081 & 0.0325 & 0.0407 & -0.0094 & 0.0843 \\
Job Resources & 0.2774 & 0.1676 & 0.4450 & 0.0932 & 0.2607 \\
\hline TOTAL & 0.2855 & 0.2001 & 0.4857 & & \\
\hline \hline
\end{tabular}

Table 2: Pearson Produce Moment Correlation Analysis

\begin{tabular}{lll}
\hline \hline Variables & $\mathbf{1}$ & $\mathbf{2}$ \\
\hline In-role Performance & - & \\
Flow & $0.416^{* *}$ & - \\
\hline \hline
\end{tabular}

Notes: ** Correlation is significant at the 0.01 level (2-tailed). 
Pearson product moment correlation coefficient was deployed to test the third hypotheses. The result revealed that the two variables was positively significant related $[0.416, n=290, p=0.000]$. Hence the hypothesis was supported. Flow is positively related to in-role performance. In line with previous research, flow predicted job performance (Byrne, MacDonald, \& Carlton, 2003) and motivation (Barrick \& Mount, 2005; Li et al., 2012). This result is similarly demonstrated by Bakker et al. (2004) that engaged individuals have better in-role job performance. Another reason proclaimed that employees experience flow often feel positive emotions and it could be the justification for employees in greater productivity level. Bakker \& Demerouti (2008) reported that employees who experienced flow often felt positive emotion and this could be attributed to their greater productivity level. These findings can thus substantiate why hotel employees may be able to perform better when they encounter flow experience in their work environment. Thus, that explain why hotel employees in the study will perform better when they encounter flow experience in their work environment toward service climate.

\section{LIMITATION AND FUTURE RESEARCH RECOMMENDATION}

In this study, a cross-sectional approach yield to no clarity about causation. Correlation between the variables have been interpreted rather than established. As advised by Schaufeli and Bakker (2004), longitudinal studies should be employed to establish the causal relationships amongst the variables. In addition, the use of respondents' quantitative diary study is recommended to collect data a few times a day to understand about their flow behaviors, activities, and experiences. The setting and unit of population also can be expanded to other regions across Malaysia to include the states in Peninsular Malaysia. This may provide more rich and in-depth data which can lead to better informed studies about employee burnout and engagement and organizational performance and high level of generalization results.

\section{LIMITATION AND FUTURE RESEARCH RECOMMENDATION}

Firstly, the present study points that interventions from higher management which emphasizes on empowering job resources - such as autonomy, social support from colleagues and performance feedback - may further promote the occurrence of flow experience among hotel employees which leads to creating employees that are well engaged and productive. For instance, the managers can set a more precise performance goals which need to be achieved by the employees. They can update and provide the employees with information concerning to their work on a regular basis, and they should inform and provide essential information and/ or tools that are crucial for employees to achieve their work tasks. Our study also suggests that employees that are engaged (experiencing flow) are highly likely to achieve their official work tasks excellently as compared to their counterparts who do not experience flow (Bakker et al., 2004). Moreover, it is also shown in this study that when employees who are provided with sufficient job resources while experiencing flow at the same time, will carry out their formally obligated work in a better manner. It is vital for hotel management to develop a work environment that promotes flow experience and provide a sufficient supportive working environment and job design that emphasize the provision of job resources. Hence, organizations should redesign game plan that focuses on enriching the work environment and job characteristics that facilitate the experience of flow while also empowering 
their employees with job resources in order to achieve better organizational performance to remain competitive and retain profit.

Further, the evidence of this study shows that flow influences in-role performance positively and it mediates the relationship between job resources (autonomy, social support, performance feedback, possibilities for professional development) and in-role performance. This can help the organization, particularly human resource practitioners, to gain insight to which extent developing a flow-prone work environment and job characteristic can facilitate the employees engaging (flow experience) in their work tasks. It is important that organizations understand how to promote flow experience among the employees as preceding studies have found that engaged employees perform better and more productively (Bakker, et al, 2004;) will lead to higher organization performance, particularly in financial terms. Besides that, theoretically it helps to promote improved understanding among hoteliers - particularly the higher management and Human Resource department - the importance of (1) creating work environment that facilitates flow experience among hotel employees and (2) consistently supporting the hotel employees with sufficient supportive work environment. The current study has also contributed to the knowledge of flow experience as mediator and its effect on the relationship between JD-R and in-role performance, particularly in the eastern context in the service industry.

To have a better service climate in hotels, management should ensure that the tasks given to their employees will generate flow because evidence suggests that this can positively affect job satisfaction and performance. This in turn will positively affect service quality services and customer satisfaction. The advocacy to encourage flow in the hotel setting is prudent: job requirements matching skill sets have shown to result in higher satisfaction and psychological and psychosocial wellbeing, all of which increases employee in-role performance. It was found that within the hotel setting, surprisingly, flow experience will occur with the presence of supportive job resources. Hotel management should give certain tasks autonomy. Having ownership of one's work is a recognized motivator. Providing a positive avenue for coaching by relevant supervisors can foster a supportive social working environment and employees may identify progressive career would see there are possibilities. This may encourage hotel employees to concentrate more effort into their tasks and this may directly benefit their organization in the long run in terms of productivity and financial performance.

In a nutshell, the current study is helpful to the pertinent industries and organizations within it via providing insights that guide the industry professionals (such as hotel directors and managers) in the workplace. Using the knowledge provided by the current study, hospitality industry professionals ought to take into account the development of strategies that may help in promoting flow experience among the employees. This will lead to an increase in in-role performance that in turn contributes towards obtaining overall organizational performance and goals. Moreover, promoting flow experience by providing adequate amount of job resources while supporting a flow-promoting workplace may help to increase individual's satisfaction at work which allows the organization to improve employee retention. Lastly, undesirable backlash of job demands that might result to burnout, can be buffered by providing workplace that is of flow-promoting nature. 


\section{ACKNOWLEDGEMENT}

The paper is supported by Universiti Malaysia Sarawak (UNIMAS), GrantF04/DPD/1626/2017 Work-Related Flow Inventory (WOLF): Validation and Testing in Asian Context.

\section{REFERENCES}

Amin, Z., \& Akbar, K. P. (2013). Analysis of psychological well-being and turnover intentions of hotel employees: An empirical study. International Journal of Innovation and Applied Studies, 3(3), 662-671.

Ashkanasy, Wilderom, \& Peterson (2000). Handbook of organizational culture and climate. Thousand Oaks, CA: Sage.

Bakker, A. B. (2008). The work-related flow inventory: Construction and initial validation of the WOLF. Journal of Vocational Behavior, 72(3), 400-414. doi: 10.1016/j.jvb.2007.11.007

Bakker, A. B., \& Demerouti, E. (2007). The job demands-resources model: State of the art. Journal of Managerial Psychology, 22(3), 309-328, doi: 10.1108/02683940710733115

Bakker, A. B., \& Demerouti, E. (2008). Towards a model of work engagement. Career Development International, 13(3), 209-223. doi: 10.1108/13620430810870476

Bakker, A. B., Demerouti, E., \& Lieke, L. (2012). Work engagement, performance, and active learning: The role of conscientiousness. Journal of Vocational Behavior, 80(2), 555-564. doi:10.1016/j.jvb.2011.08.008

Bakker, A. B., Demerouti, E., \& Schaufeli, W. B. (2003). Dual processes at work in a call centre: An application of the Job Demands-Resources model. European Journal of Work and Organizational Psychology, 12(4), 393-417. doi:10.1080/13594320344000165

Bakker, A. B. and Demerouti, E. \& Verbeke, W. (2004), Using the job demands: Resources model to predict burnout and performance. Human Resource Management, 43(1), 83-104, doi: $10.1002 / \mathrm{hrm} .20004$

Bakker, A. B., Demerouti, E., De Boer, E. \& Schaufeli, W. B. (2003), Job demands and job resources as predictors of absence duration and absence frequency. Journal of Vocational Behavior, 62(2), 341-356, doi: 10.1016/S0001-8791(02)00030-1

Bakker, A. B., Demerouti, E., Taris, T., Schaufeli, W. B., \& Schreurs, P. (2003). A multi-group analysis of the job demands-resources model in four home care organizations. International Journal of Stress Management, 10(1), 16-38.

Barrick, M. R., Mount, M. K. (2005). Yes, personality matters: Moving on to more important matters. Human Performance, 18(4), 341-356. doi: 10.1016/S0001-8791(02)00030-1

Britt, T. W. (2003). Aspects of identity predict engagement in work under adverse conditions. Self and Identity, 2(1), 31-45, doi: 10.1080/15298860309022

Brown, E. A., Thomas, N. J., \& Bosselman, R. H. (2015). Are they leaving or staying: A qualitative analysis of turnover issues for Generation Y hospitality employees with a hospitality education. International Journal of Hospitality Management, 46, 130-137, doi: 10.1016/j.ijhm.2015.01.011

Byrne, C., MacDonald, R., \& Carlton, L. (2003). Assessing creativity in musical compositions: Flow as assessment tool. British Journal of Music Education, 20(3), 277-290, doi: $10.1017 / \mathrm{S} 0265051703005448$

Catley, D., \& Duda, J. L. (1997). Psychological antecedents of the frequency and intensity of flow in golfers. International Journal of Sport Psychology, 28(4), 309-322. 
Chen, H., Wigand, R. T., \& Nilan, M. S. (1999). Optimal experience of Web activities. Computers in Human Behaviour; 15(5), 585-608, doi: 10.1016/S0747-5632(99)00038-2

Cooper, D., \& Schindler, P. (2003). Business research methods (8 ed.). New York: McGraw-Hill. Csikszentmihalyi, M., (1990). Flow: The Psychology of optimal experience. New York: Harper and Row.

Csikszentmihalyi, M. (1997). Finding flow: The psychology of engagement with everyday life. New York: Harper Collins.

Csikszentmihalyi, M. (2003). Good Business, Leadership, flow, and the making of meaning. USA: Penguin Books.

Csikszentmihalyi, M., \& LeFevre, J. (1989). Optimal experience in work and leisure. Journal of Personality and Social Psychology, 56, 815-822.

Davis, G. (2013). Staff turnover in hospitality. Retrieved October 31, 2018, from http://www.insidebusiness360.com/index.php/staff-turnover-in-hospitality-2-10167/

De Clercq, D., Dimov, D., \& Thongpapanl, N. T. (2010). The moderating impact of internal social exchange processes on the entrepreneurial orientation-performance relationship. Journal of business venturing, 25(1), 87-103. doi: 10.1016/j.jbusvent.2009.01.004

Deloitte, (2010). Hospitality 2015: Game changers or spectators. London, England.

Demerouti, E. (2006) Job Characteristics, flow and performance: The moderating role of conscientiousness. Journal of Occupational Health Psychology, 1(3), 266-280. doi: 10.1037/1076-8998.11.3.266

Demerouti, E., Bakker, A. B., Nachreiner, F., \& Schaufeli, W. (2000). A model of burnout and life satisfaction amongst nurses. Journal of Advanced Nursing, 32(2), 454-464.

Demerouti, E., Bakker, A., Nachreiner, F., \& Schaufeli, W. (2001). The job demands-resources model of burnout. Journal of Applied Psychology, 86(3), 499-512. doi:10.1037/00219010.86.3.499

Diener, E. (2000). Subjective well-being: The science of happiness and a proposal for a national index. American psychologist, 55(1), 33-34.

Diener, E., \& Diener, C. (1996). Most people are happy. Psychological Science, 7(3), 181-185.

Dimond, D. (2004). Don't build; make better. Lodging Hospitality, 60(6), 40-41.

Edwards, J. R. (1996). An examination of competing versions of the person-environment fit approach to stress. Academy of Management Journal, 39(2), 292-339.

Engeser, R., Jones, J. R., Stiglhamber, F., Shanock, L., \& Randall, A. T. (2005). Flow experiences at work: For high need achievers alone?. Journal of Organizational Behaviour, 26(7), 755-775. doi:10.1002/job.337

Furda, J. (1995). Werk, persoon en welzijn: Eentoets van het JD-C model [Work, personality, and well-being: A test of the JD-C model]. Unpublished doctoral dissertation, Utrecht University, Netherlands.

George, J. M., \& Brief, A. P. (1992). Feeling good-doing good: A conceptual analysis of the mood at work-organizational spontaneity relationship. Psychological Bulletin 112(2), 310-329.

Geurts, S. A. E. (2000). SWING: Survey work-home interference Nijmegen. Internal research report. Nijmegen, Netherlands: University of Nijmegen.

Hakanen, J. J., Bakker, A. B., \& Schaufeli, W. B. (2006). Burnout and work engagement among teachers. Journal of school psychology, 43(6), 495-513. doi: 10.1016/j.jsp.2005.11.001

Hallberg, U. E., \& Schaufeli, W. B. (2006). "Same same" but different? Can work engagement be discriminated from job involvement and organizational commitment? European psychologist, 11(2), 119-127. doi: 10.1027/1016-9040.11.2.119 
Hamid, S. N. A., \& Yahya, K. K. (2011). Relationship between person-job fit and personorganization fit on employees' work engagement: A study among engineers in semiconductor companies in Malaysia. In Annual Conference on Innovations in Business and Management London, 6, pp. 1-30.

Harter, J. K., Schmidt, F. L., \& Hayes, T. L. (2002). Business-unit-level relationship between employee satisfaction, employee engagement, and business outcomes: A meta-analysis. Journal of applied psychology, 87(2), 268-279. doi: 10.1037/0021-9010.87.2.268

Hayes, D. K., \& Ninemeier, J. D. (2007). Human resources management in the hospitality industry. Hoboken: John Wiley \& Sons, Inc.

Hockey, G. J. (1997). Compensatory control in the regulation of human performance under stress and high workload: A cognitive - energetical framework. Biological Psychology, 45(13), 73-93.

Ismail, M., \& Azmi, N. (2019, February 27). Tourism contributes rm84.1 billion to malaysia economy with 25.8 million tourists in 2018. Retrieved from Tourism Malaysia: https:/www.tourism.gov.my/media/view/tourism-contributes-rm84-1-billion-tomalaysia-economy-with-25-8-million-tourists-in-2018

Kaiser, H. F. (1974). An Index of Factorial Simplicity. Psychometrika, 39(1), 31-36. doi: $10.1007 / \mathrm{BF} 02291575$

Karasek, R. (1985). Job content instrument: Questionnaire and user's guide, revision 1.1. Department of Industrial and Systems Engineering. Los Angeles: University of Southern California.

Karatepe, O. M., \& Olugbade, O. A. (2009). The effects of job and personal resources on hotel employees' work engagement. International Journal of Hospitality Management, 28(4), 504-512. doi: 10.1016/j.ijhm.2009.02.003

Kasa, M., \& Hassan, Z. (2013). Antecedent and consequences of flow: Lessons for developing human resources. Procedia-Social and Behavioral Sciences, 97, 209-213.

Kasa, M., \& Hassan, Z., \& Yatim, A. (2018). Does Flow Experience Really Matter among Hotel Employees in Sarawak? International Journal of Engineering and Technology. 7(3.30), 11-14.

Kowal, J., \& Fortier, M. S. (1999). Motivational determinants of flow: Contributions from selfdetermination theory. The Journal of Social Psychology, 139(3), 355-368. doi: $10.1080 / 00224549909598391$

Lewicka, D. (2011). Creating innovative attitudes in an organisation - Comparative analysis of tools applied in IBM Poland and ZPAS Group. Journal of Asia Pacific Business Innovation and Technology Management. 1(1), 1-12

Li, C., Chen, L., Chang, J., \& Kun, F. (2012). Team Members' Flow Experiences and their Influence on Project Performance. The Journal of Human Resource and Adult Learning, $8(1), 46-55$.

MacKinnon, D. P., Fairchild, A. J., \& Fritz, M. S. (2007). Mediation analysis. Annual Review of Psychology, 58, 593-614. doi: 10.1146/annurev.psych.58.110405.085542

MacKiinnon, D. P., Lockwood, C. M. \& William, J. (2004). Confidence limits of the indirect effect: Distribution of the product and resampling methods. Multivariate Behavioral Research, 39(1), 99. doi: 10.1207/s15327906mbr3901 4

Mahidin, U. (2019). Employment Statistics First Qüarter 2019. Kuala Lumpur: Department Of Statistics Malaysia. 
Makikangas, A., Bakker A. B., Aunola, K., \& Demerouti, E. (2010). Job Resources and flow at work: Modelling the relationship via latent growth curve and mixture model methodology. Journal of Occupational Psychology; 83(3), 795-814. doi: 10.1348/096317909X476333

Malaysian Investment Development Authority. (2019). Hospitality. Retrieved from Malaysian Investment Development Authority: http://www.mida.gov.my/home/hospitality/posts/

Mauno, S., Kinnunen, U., \& Ruokolainen, M. (2007). Job demands and resources as antecedents of work engagement: A longitudinal study. Journal of Vocational Behavior, 70(1), 149171. doi: 10.1016/j.jvb.2006.09.002Get

May, D. R., Gilson, R. L., \& Harter, L. M. (2004). The psychological conditions of meaningfulness, safety and availability and the engagement of the human spirit at work. Journal of Occupational and Organizational Psychology, 77(1), 11-37. doi: 10.1348/096317904322915892

Mokaya, S. O., Musau, J. L., Wagoki, J., \& Karanja, K. (2013). Effects of organizational work conditions on employee job satisfaction in the hotel industry in Kenya. International Journal of Arts and Commerce, 2(2), 79-90.

Motowidlo, S. J. and Van Scotter, J. R. (1994). Evidence That Task Performance Should Be Distinguished from Contextual Performance. Journal of Applied Psychology, 79(4), 475480. doi: 10.1037/0021-9010.79.4.475

Mulyana, A., \& Prayetno, S. (2018, September). Determinants of Customer Satisfaction and It's Implication on Customer Loyalty of Budget Hotel in DKI Jakarta. International Review of Management and Marketing. EconJournals.

Ng, K. (2015). Malaysia's Hospitality Industry_What Are the Talent Challenges? | Aon Hewitt $A P A C$. Retrieved from https://apac.aonhewitt.com/home/insights-at-work/talentchallenges-malaysia-hospitality-industry

Parker, S. L., Jimmieson, N. L., \& Amiot, C. E. (2010). Self-determination as a moderator of demands and control: Implications for employee strain and engagement. Journal of Vocational Behavior, 76(1), 52-67. doi: 10.1016/j.jvb.2009.06.010

Preacher, K, J., \& Hayes, A. F., (2004). SPSS and SAS procedures for estimating indirect effects in simple mediation models. Behavior Research Methods, Instruments, \& Computers, 36(4), 717-731. doi: 10.3758/BF03206553

Reena, \& Jayan. (2012). Role of Quality of Work Like on The Job Attitude and Personal Effectiveness of Engineering College Teachers. An International Multidisciplinary Research Journal, 2(6).

Saks, A. M. (2006). Antecedents and consequences of employee engagement. Journal of Managerial Psychology, 21(7), 600-619. doi: 10.1108/02683940610690169

Salanova, M., Agut, S., \& Peiró, J. M. (2005). Linking organizational resources and work engagement to employee performance and customer loyalty: The mediation of service climate. Journal of Applied Psychology, 90(6), 1217-1227. doi: 10.1037/00219010.90.6.1217

Schaufeli, W. B., \& Bakker, A. B. (2004). Job demands, job resources, and their relationship with burnout and engagement: A multi-sample study. Journal of Organizational Behavior, 25, 293-315. doi: 10.1002/job.248

Straume, L. V., \& Vittersø, J. (2015). Well-being at work: Some differences between life satisfaction and personal growth as predictors of subjective health and sick-leave. Journal of Happiness Studies, 16(1), 149-168. doi: 10.1007/s10902-014-9502-y

Van Veldhoven, M., \& Meijman, T. F. (1994). The measurement of psychosocial strain at work: The questionnaire experience and evaluation of work. Amsterdam: NIA. 
Veenhoven, R. (1999), Quality of Life in Individualistic Society: A Comparison of 43 nations in the early 1990's. Social Indicator Research, 48, 157-86.

Veenhoven, R. (1984), Conditions of Happiness, Dordrecht: D. Reidel Publishing Company.

Tourism Sector to remain the third largest contributor to economy. (2017, September 26). The Star. Retrieved from https://www.thestar.com.my/business/businessnews/2017/09/26/tourism-sector-to-remain-third-largest-contributor-toeconomy/\#HULJ7gXGSqICqSFX.99 [Accessed 27 Oct. 2018].

Turner, R. (2018). Economic Impact 2018 Malaysia. Retrieved from London, United Kingdom: World Travel \& Tourism Council (WTTC) website: https://www.wttc.org//media/files/reports/economic-impact-research/countries-2018/malaysia2018.pdf

Weigl, M., Hornung, S., Parker, S. K., Petru, R., Glaser, J., \& Angerer, P. (2010). Work engagement accumulation of task, social, personal resources: A three-wave structural equation model. Journal of Vocational Behavior, 77(1), 140-153. doi: 10.1016/j.jvb.2010.03.002

Williams, L. J., \& Anderson, S.E. (1991), Job satisfaction and organizational commitment as predictors of organizational citizenship and in-role behaviors. Journal of Management, 17(3), pp. 601-617. doi: 10.1177/014920639101700305

Xanthopoulou, D., Bakker, A. B., Demerouti, E., \& Schaufeli, W. B. (2007). The role of personal resources in the job demands-resources model. International journal of stress management, 14(2), 121-141. doi: 10.1037/1072-5245.14.2.121

Xanthopoulou, D., Bakker, A. B., Demerouti, E., \& Schaufeli, W. B. (2009). Reciprocal relationships between job resources, personal resources, and work engagement. Journal of Vocational behavior, 74(3), 235-244. doi: 10.1016/j.jvb.2008.11.003

Xie, J., \& Chaipoopirutana, S. (2014). An Examination of the Influencing Factors toward Customer Satisfaction: Case study of a Five Star Hotel in Bangkok, Thailand. In International Conference on Business, Law and Corporate Social Responsibility (ICBLCSR'14) Oct 12, 2014. Phuket, Thailand.

Zhou, T., Li, H. X., \& Liu, Y. (2010) The effect of flow experience on mobile SNS users' loyalty. Industrial Management and Data Systems. 110(6), 930-946. doi: 10.1108/02635571011055126 